\title{
The Ethanolic Stem-Bark Extract of Antrocaryon micraster Inhibits Carrageenan-Induced Pleurisy and Pedal Oedema in Murine Models of Inflammation
}

\author{
Leslie B. Essel, ${ }^{1}$ David D. Obiri, ${ }^{1}$ Newman Osafo, ${ }^{1}$ \\ Aaron O. Antwi, ${ }^{1}$ and Babatunde M. Duduyemi ${ }^{2}$ \\ ${ }^{1}$ Department of Pharmacology, Faculty of Pharmacy and Pharmaceutical Sciences, College of Health Sciences, \\ Kwame Nkrumah University of Science \& Technology (KNUST), Kumasi, Ghana \\ ${ }^{2}$ Department of Pathology, School of Medical Sciences, College of Health Sciences, Kwame Nkrumah University of \\ Science \& Technology (KNUST), Kumasi, Ghana \\ Correspondence should be addressed to David D. Obiri; ddobiri.pharm@knust.edu.gh
}

Received 25 February 2017; Revised 29 May 2017; Accepted 13 June 2017; Published 17 July 2017

Academic Editor: Suhel Parvez

Copyright (c) 2017 Leslie B. Essel et al. This is an open access article distributed under the Creative Commons Attribution License, which permits unrestricted use, distribution, and reproduction in any medium, provided the original work is properly cited.

We investigated the antioxidant and anti-inflammatory effects of a $70 \% \mathrm{v} / \mathrm{v}$ ethanol extract of the stem bark of Antrocaryon micraster on murine models of carrageenan-induced pleurisy and paw oedema. Rat pleural fluid was analysed for volume, protein content, and leucocytes, while lung histology was assessed for damage. Lung tissue homogenates were assayed for glutathione (GSH), superoxide dismutase (SOD), catalase (CAT), malondialdehyde (MDA), and myeloperoxidase (MPO). Phytochemical analysis was carried out on the stem bark. Acute toxicity studies were conducted in rats. In the pleurisy model the extract (30-300 mg/kg) significantly reduced the volume and amount of proteins and leucocytes in the exudate and also protected against lung injury. Tissue level of GSH and SOD and CAT expression were increased while MDA level and MPO activity were reduced. The peak and total oedema responses were significantly suppressed when given both preemptively and curatively in the mice paw oedema test. Saponins, alkaloids, triterpenoids, and tannins were present in the stem bark. A. micraster extract exhibited no apparent acute toxicity. We conclude that the ethanolic stem-bark extract of A. micraster has antioxidant action and exhibits significant anti-inflammatory activity through suppression of pleurisy and paw oedema induced with carrageenan.

\section{Introduction}

Antrocaryon micraster (Anacardiaceae) is a deciduous tree which reaches heights of $40-50 \mathrm{~m}$. The tree is harvested for timber and is listed as "Vulnerable" in the International Union for the Conservation of Nature (IUCN) Red List of Threatened Species (2011) [1] and exists mostly in tropical semideciduous forests in Cameroon through Ghana to Uganda [2]. It is called "Aprokuma" in local Ghanaian communities [3] and has been noted as a medicinal plant. Medicinal plants are a rich and important source of diverse biologically active compounds which have been used as lead compounds and optimized to improve efficacy [4]. Information obtained through ethnobotanical interviews in local Ghanaian communities reveal that the stem bark, root, and leaves are boiled with water to treat malaria [5] and also rubbed on the body to treat chicken pox when it is ground with seeds of Xylopia aethiopica and Aframomum melegueta [3]. The fruits or stem bark prepared in a poultice are also taken or applied, respectively, to relieve pain and arthritic joints [6], an indication of its anti-inflammatory effect.

Inflammation is a complex process which represents a tissue's response to local injury and may result from physical and chemical insult as well as invasion by microorganisms [7] and is characterized by the classical features of oedema, redness, heat, pain, and loss of function [8]. A series of responses known as the acute inflammatory response is mounted which then isolates the site of injury or infection and/or eradicates the offending agent ultimately leading to tissue repair (sometimes with scaring) or tissue death [9, 10]. The inflammatory process is a defensive process and functions primarily to protect the tissue from further damage 
[11]. However, if the process is not properly regulated, or the offending agent persists, the intended protective process tends to be destructive: the underlying cause of inflammatory diseases which require pharmacological intervention [12].

Drug groups such as steroidal and nonsteroidal antiinflammatory drugs and biologics have been developed for the management of inflammatory conditions. However, use of these drugs is limited by high costs, long duration of therapy, and adverse effects $[13,14]$. Consequently, there is a renewed interest in medicinal plant research to identify alternate agents which may be cheaper and have less or no adverse effects [15].

Unfortunately, there is no report in literature to support the folklore use of any part of A. micraster plant in inflammatory disorders. This study therefore seeks to evaluate the aqueous ethanol extract of the stem bark of A. micraster on acute inflammation and its antioxidant properties in murine models with the view of finding a justification for its use in the management of the inflammatory conditions.

\section{Materials}

2.1. Plant Material. Stem bark of Antrocaryon micraster was harvested from Kwahu-Asakraka, Ghana $\left(6^{\circ} 37^{\prime} 37.2072^{\prime \prime} \mathrm{N}\right.$; $\left.0^{\circ} 41^{\prime} 23.0352^{\prime \prime} \mathrm{W}\right)$, in February 2015. The plant material was identified and authenticated by Professor Abraham Yeboah Mensah and a voucher specimen deposited in the herbarium of the Department of Pharmacognosy, Faculty of Pharmacy \& Pharmaceutical Sciences, KNUST, Kumasi. The plant material was air-dried for 2 weeks, pulverized, and cold macerated with ethanol $(70 \% \mathrm{v} / \mathrm{v})$ for $72 \mathrm{~h}$. The filtrate was concentrated under pressure and oven-dried at a constant temperature of $50^{\circ} \mathrm{C}$ for $24 \mathrm{~h}$. A dark brown paste representing a yield of $7.46 \% \mathrm{w} / \mathrm{w}$ was obtained. When required the paste was reconstituted in normal saline $(0.9 \% \mathrm{w} / \mathrm{v} \mathrm{NaCl})$ and hereby referred to as $A$. micraster extract (AME) in the pharmacological investigations.

2.2. Animals. Sprague Dawley rats (200-250 g) and Imprint Control Region (ICR) mice (20-25 g) were obtained from the Animal House, Department of Pharmacology, KNUST. Animals were housed under hygienic conditions in metal cages with wood shavings as bedding material and maintained at a $12 \mathrm{~h}$ light-dark cycle. The animals had free access to standard chow and clean water. All animals were humanely handled throughout the experimental period in accordance with Animal Welfare Regulations (USDA 1985; US Code, 42 USC $\$ 289 d$ ) and the Public Health Service Policy on Humane Care and Use of Laboratory Animals (PHS 2002). All experiments were approved and clearance for commencement of the experiments was given by the Ethics Committee of the Department of Pharmacology, KNUST. Animals were humanely euthanised at the end of each experiment.

2.3. Drugs and Chemicals. Drugs and chemicals were obtained from the following sources; $\lambda$-carrageenan, Triton X-100, 5,5-dithio bis-2-nitrobenzoic acid (DTNB) [Sigma-Aldrich Inc., St. Louis, MO, USA]; trichloroacetic acid (TCA), thiobarbituric acid (TBA), potassium dichromate, formic acid sodium bicarbonate, chloroform, and disodium hydrogen phosphate [BDH, Poole, England]; Tris(hydroxymethyl)aminomethane and ethylenediaminetetraacetic acid (EDTA) [Techno Pharmchem Haryana, India]; diclofenac sodium [Troge, Hamburg, Germany]; sodium dihydrogen orthophosphate monohydrate [Hopkins \& Williams Ltd., Swansea, Wales]; formalin, acetic acid, and analytical grade glacial acetic acid [VWR Chemicals, France]; ethanol and hydrogen peroxide [Bells Sons \& Co. Ltd., Southport, England]; Complete Protease Inhibitor Cocktail Tablet, EDTA-free [Santa Cruz Biotechnology, Dallas, TX, USA]; glycerol and diethyl ether [Surechem Products Ltd., England].

\section{Methods}

3.1. Carrageenan-Induced Pleurisy in Sprague Dawley Rats. A method described earlier by Saleh et al. was employed [16]. Briefly, five groups of test animals $(n=5)$ were treated with either normal saline $(5 \mathrm{ml} / \mathrm{kg})$, diclofenac $(10 \mathrm{mg} / \mathrm{kg})$, or A. micraster extract $(30,100$ and $300 \mathrm{mg} / \mathrm{kg}$ ) daily for 3 days. Under light ether anaesthesia, pleurisy was induced in the test animals by an injection of $100 \mu$ l sterile carrageenan suspension ( $1 \% \mathrm{w} / \mathrm{v}$ in normal saline) into the right pleural space $1 \mathrm{~h}$ after last drug treatment. The naïve control group $(n=5)$ received intrapleural injection of $100 \mu$ l sterile normal saline only. After $4 \mathrm{~h}$, rats were sacrificed with an overdose of diethyl ether, their thoraxes carefully opened, and the pleural cavities rinsed with $2 \mathrm{ml}$ EDTA ( $1 \% \mathrm{w} / \mathrm{v}$ in normal saline). The exudate and rinse solutions were removed by aspiration and blood contaminated recovered fluid was discarded. The exudate was subjected to the following tests.

3.1.1. Exudate Volume and Total Protein Content. The volume of exudate that leaked into the pleural cavity was calculated as the difference in the volumes of rinse and recovered fluids. Protein content was determined with an automated Clinical Analyser (Flexor Junior, Vital Scientific B.V., Netherlands).

3.1.2. Leucocyte Cell Count. Total and differential count of leucocytes in the exudate were done with an automated analyser (Sysmex KX-21N, Sysmex America Inc., Illinois, USA).

3.1.3. Histopathology of Lung Tissue. Lung tissues were carefully removed from the rats and fixed in formalin (10\%). Tissues were serially dehydrated in increasing concentrations of ethanol, cleared in xylene in a TP 1020 Tissue processor (Leica Biosystems, Wetzlar, Germany), and embedded in paraffin using a Leica EG 1160 Embedding machine (Leica Biosystems, Wetzlar, Germany). Transverse sections of $5 \mu \mathrm{m}$ were cut with a Leica RM 2125 Microtome (Leica Biosystems, Wetzlar, Germany), deparaffinized, and hydrated to distilled water and stained with haematoxylin and eosin ( $\mathrm{H} \& \mathrm{E})$. The slides were viewed under a digital light microscope (DM 750, Leica Microsystems, Wetzlar, Germany) fitted with a digital camera (ICC 50 HD, Leica Microsystems, Wetzlar, Germany). 
3.2. Biochemical Assays for Oxidative Stress Markers. Sprague Dawley rats were randomized into 6 groups $(n=5)$ and either untreated or treated, respectively, with normal saline $(5 \mathrm{ml} / \mathrm{kg})$, diclofenac $(10 \mathrm{mg} / \mathrm{kg})$, or A. micraster extract (30, 100 , or $300 \mathrm{mg} / \mathrm{kg}$ ) p.o. daily for 3 days. One hour after the last treatment, pleurisy was induced with carrageenan as earlier described in test animals with the naïve control group receiving intrapleural injection of $100 \mu \mathrm{l}$ sterile normal saline only. After $4 \mathrm{~h}$, the animals were sacrificed and lung tissues removed, washed with PBS ( $\mathrm{pH}$ 6.0), homogenized in icecold buffer [Triton X-100 (1\%), protease inhibitor cocktail, Tris $\mathrm{HCl}(150 \mathrm{mM}), \mathrm{NaCl}(150 \mathrm{mM})$, and glycerol (10\%), $\mathrm{pH}$ 7.4] to obtain a $10 \% \mathrm{w} / \mathrm{v}$ homogenate, and centrifuged at $5200 \times \mathrm{g}$ for $20 \mathrm{~min}$. The protein content in the supernatant was quantified using the Bradford method. The remaining samples were stored at $-80^{\circ} \mathrm{C}$ and when needed aliquoted in triplicate and subjected to biochemical assays using the Synergy H1 Hybrid Multi-Mode Microplate Reader (BioTek Technologies, Winooski, VT, USA) for the following oxidative stress markers.

3.2.1. Reduced Glutathione (GSH). GSH levels were determined by a method earlier described by Ellman [17]. Briefly, $100 \mu \mathrm{l}$ aliquot of tissue extract was mixed with $2.4 \mathrm{ml}$ EDTA $(0.02 \mathrm{M})$ at $4^{\circ} \mathrm{C}$ for $10 \mathrm{~min}$. To this $2 \mathrm{ml}$ distilled water and $500 \mu \mathrm{l} \mathrm{TCA}(50 \% \mathrm{w} / \mathrm{v})$ were added and centrifuged at $1300 \times \mathrm{g}$ for $5 \mathrm{~min}$. To $1 \mathrm{ml}$ of the supernatant, $50 \mu \mathrm{l} 5,5^{\prime}$-dithio-bis2-nitro benzoic acid, DTNB $(10 \mathrm{mM})$, and $2 \mathrm{ml}$ Tris buffer (0.4 M, pH 8.9) were added. Absorbance was read within 5 min of DTNB addition at $412 \mathrm{~nm}$ against a blank (reagents only). The final sulphydryl concentration was extrapolated from a standard curve.

3.2.2. Superoxide Dismutase (SOD) Activity. SOD activity was estimated with a modified method as earlier described by Misra and Fridovich [18]. Briefly, $500 \mu \mathrm{l}$ tissue supernatant was added to $150 \mu \mathrm{l}$ ice-cold chloroform and $750 \mu \mathrm{l}$ ethanol $(96 \% \mathrm{v} / \mathrm{v})$, vortexed for $1 \mathrm{~min}$, and then centrifuged at $600 \times \mathrm{g}$ for $20 \mathrm{~min}$. To $500 \mu \mathrm{l}$ portion of the supernatant, $500 \mu \mathrm{lEDTA}$ $(0.6 \mathrm{mM})$ and $1 \mathrm{ml}$ carbonate bicarbonate buffer $(0.1 \mathrm{M}, \mathrm{pH}$ 10.2 ) were added. The reaction was initiated by the addition of $50 \mu \mathrm{l}$ adrenaline $(1.3 \mathrm{mM})$. Absorbance was measured at $480 \mathrm{~nm}$ against a blank. Activity of SOD, measured as the quantity of the enzyme required to inhibit the autooxidation of adrenaline, was then computed. SOD activity was expressed in units per mg protein, where 1 unit of enzyme activity is the quantity of enzyme required to prevent the autooxidation of adrenaline at $25^{\circ} \mathrm{C}$.

3.2.3. Catalase (CAT) Activity. The method described by Sinha with slight modifications was used [19]. Briefly, to a $100 \mu \mathrm{l}$ aliquot of tissue supernatant, $1 \mathrm{ml}$ phosphate buffer (0.01 M, pH 7.0) and $400 \mu \mathrm{l} \mathrm{H}_{2} \mathrm{O}_{2}(1.18 \mathrm{M})$ were added and the mixture was incubated at room temp for $5 \mathrm{~min}$. The reaction was halted by adding $2 \mathrm{ml}$ of a 3:1 mixture of glacial acetic acid and dichromate (5\%). Absorbance was measured at $620 \mathrm{~nm}$. One unit of catalase activity, defined as the amount of enzyme that degrades $1 \mathrm{mmol}_{2} \mathrm{O}_{2}$ per min at $25^{\circ} \mathrm{C}$ and $\mathrm{pH}$
7.0, was expressed in terms of its molar extinction coefficient, $39.4 \mathrm{M}^{-1} \mathrm{~cm}^{-1}$.

3.2.4. Myeloperoxidase (MPO) Activity. MPO activity was determined by means of a modified $o$-dianisidine method described by Şenoğlu et al. [20]. Briefly, $150 \mu$ l of the mixture consisting of $5 \mathrm{ml}$ of freshly prepared $0.02 \mathrm{M} o$-dianisidine in deionized water, $3 \mathrm{ml}$ phosphate buffer $(0.1 \mathrm{M}, \mathrm{pH} 6.0)$, and $3 \mathrm{ml} \mathrm{H} \mathrm{H}_{2} \mathrm{O}_{2}(0.01 \mathrm{M})$ in a final volume of $30 \mathrm{ml}$ was pipetted into 96-well plates in triplicate. To this, $10 \mu \mathrm{l}$ of tissue extract supernatant was added and the change in absorbance read immediately at $460 \mathrm{~nm}$ every $\min$ for $10 \mathrm{~min}$. One unit of MPO increases absorbance by $0.001 / \mathrm{min}$.

3.2.5. Lipid Peroxidation and Malondialdehyde (MDA). MDA was measured as a product of lipid peroxidation by the method of Heath and Packer [21]. Briefly, $1 \mathrm{ml}$ of tissue extract was added to a $3 \mathrm{ml}$ mixture of trichloroacetic acid (TCA) $(20 \%)$ and thiobarbituric acid (TBA) $(0.5 \%)$, heated at $95^{\circ} \mathrm{C}$ for $30 \mathrm{~min}$ and immediately cooled and centrifuged at $3600 \times \mathrm{g}$ for $10 \mathrm{~min} .200 \mu \mathrm{l}$ aliquots of supernatant was pipetted into 96-well plates and absorbance read at both $532 \mathrm{~nm}$ and $600 \mathrm{~nm}$, respectively, to correct for nonspecific absorbance. MDA concentration ( $\mathrm{nmol} / \mathrm{mg}$ protein) was calculated with its molar extinction coefficient of $1.56 \times$ $10^{-5} \mathrm{M}^{-1} \mathrm{~cm}^{-1}$.

3.3. Carrageenan-Induced Paw Oedema in ICR Mice. Following the method described earlier by Winter et al. pedal oedema was induced in mice [22]. In brief, mice were injected with $50 \mu \mathrm{l}$ sterile carrageenan suspension $(1 \% \mathrm{w} / \mathrm{v})$ into the subplantar tissue of the right hind paw. Oedema was monitored at $1 \mathrm{~h}$ intervals for $6 \mathrm{~h}$ with an electronic calliper (model Z22855, Milomex Ltd., Bedfordshire, UK). Drug effects were evaluated by comparing the peak (maximal) and total oedema responses attained during $6 \mathrm{~h}$ in drug-treated groups with the corresponding values attained in salinetreated inflamed control groups. Total oedema induced during the $6 \mathrm{~h}$ was determined as the area under the time course curves, AUC, and used to compute the percent inhibition of the total oedema for each treatment.

In the prophylactic protocol, drug-vehicle (saline, $5 \mathrm{ml} /$ $\mathrm{kg})$, diclofenac $(10 \mathrm{mg} / \mathrm{kg})$, or A. micraster extract $(30,100$, and $300 \mathrm{mg} / \mathrm{kg}$ ), was given orally $1 \mathrm{~h}$ prior to the induction of the oedema while in the curative protocol treatment was $1 \mathrm{~h}$ after oedema induction.

3.4. Phytochemical Screening. The powdered plant material was subjected to phytochemical screening employing methods previously described by Sofowora [23] and Evans [24], respectively.

3.5. Acute Toxicity. Sprague Dawley rats were randomized into six groups $(n=5)$, placed in observation chambers, and fasted overnight but with access to water ad libitum. The animals were treated orally with either normal saline $(5 \mathrm{ml} / \mathrm{kg})$ or A. micraster extract $(300,600,900,1200$, and $3000 \mathrm{mg} / \mathrm{kg}$ ), respectively. Animals were observed at 0,15 , $30,60,120$, and $180 \mathrm{~min}$ and $24 \mathrm{~h}$ and then daily for 14 


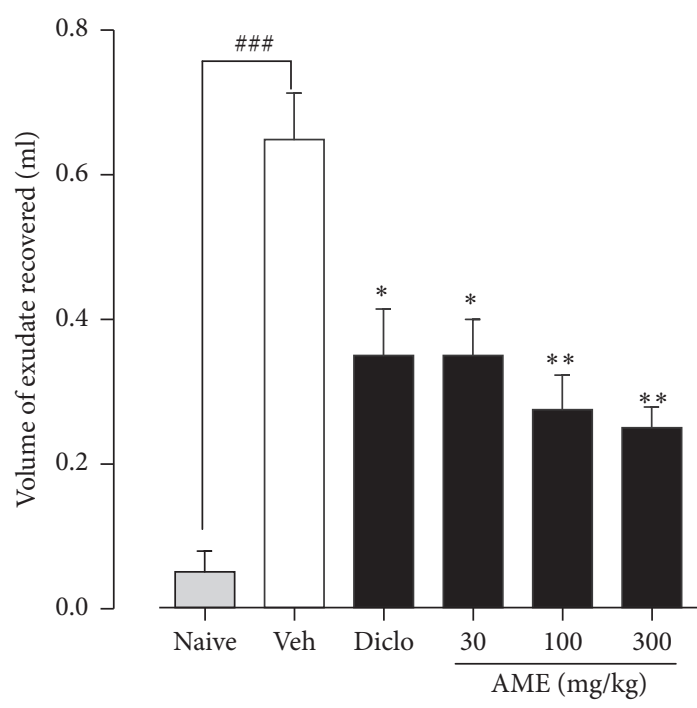

(a)

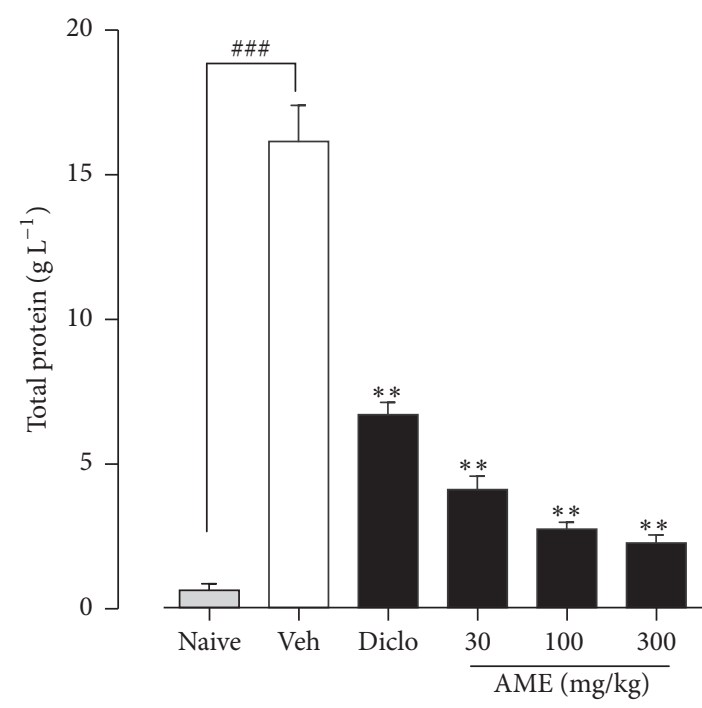

(b)

FIGURE 1: Effect of Antrocaryon micraster on the volume of exudate and total protein in carrageenan-induced pleurisy in rats. Sprague Dawley rats $(200-250 \mathrm{~g})$ were untreated or treated with either normal saline $(5 \mathrm{ml} / \mathrm{kg})$, diclofenac $(10 \mathrm{mg} / \mathrm{kg})$, or AME (30-300 mg/kg) p.o. Pleurisy was induced as described in the Methods. Volumes of exudate and total proteins were measured. Data is presented as mean \pm SEM $(n=5)$. ${ }^{*} p<0.05$ and ${ }^{* *} p<0.01$ compared to the vehicle-treated group; ${ }^{\# \# \#} p<0.001$ compared to naive control (one-way ANOVA followed by Dunnett's post hoc test).

days (delayed toxicity) for specific behaviours associated with autonomic and CNS and neurotoxicity as earlier described by Irwin [25].

3.6. Statistics. Data are presented as mean \pm standard error of mean (SEM). Statistical differences between treatment groups were determined by one-way analysis of variance (ANOVA) complemented with post hoc testing using Dunnett's correction. Analyses were carried out with GraphPad for Windows version 6.01 (GraphPad Software Inc., San Diego, CA, USA). $p$ values $<0.05$ were considered statistically significant.

\section{Results}

\subsection{Effect of Antrocaryon micraster Extract on Carrageenan-Induced Pleurisy}

4.1.1. Exudate Volume and Total Protein. Naïve animals injected with sterile saline suspension showed no signs of pleurisy and had an average recovered exudate volume of $0.05 \pm 0.03 \mathrm{ml}$ (Figure 1(a)). By the single intrapleural injection of the sterile carrageenan $(1 \% \mathrm{w} / \mathrm{v})$, test animals suffered pleurisy characterized by an accumulation of fluid containing proteins and inflammatory cells. The vehicle-treated control animals presented an average of $0.65 \pm 0.07 \mathrm{ml}$ of turbid fluid (Figure 1(a)). Treatment of the test groups with A. micraster extract $(30-300 \mathrm{mg} / \mathrm{kg})$ significantly $(p<0.01)$ reduced the volume of exudate by $46.15 \pm 5.04 \%, 57.69 \pm 4.82 \%$, and $61.54 \pm 2.91 \%$, respectively whereas diclofenac reduced the volume of exudate by $46.15 \pm 6.50 \%$ (Figure $1(\mathrm{a})$ ).

The mean total protein content in the exudates from the naïve control animals was $1.30 \pm 0.10 \mathrm{~g} / \mathrm{l}$ (Figure 1(b)) The exudate from vehicle-treated control animals contained
$16.17 \pm 1.93 \mathrm{~g} / \mathrm{l}$ of proteins. The extract-treated animals showed statistically significant reduced amounts of proteins by $74.65 \pm 2.88 \%$ and $83.15 \pm 1.45 \%$ and $86.09 \pm 1.71 \%$ at the doses used, respectively, compared with the vehicle-treated control. The exudate from the diclofenac-treated control group contained $6.70 \pm 0.64 \mathrm{gl}^{-1}$ of proteins (Figure 1(b)).

4.1.2. Leucocyte Cell Count. Analysis of the exudates revealed a total leucocyte count of $0.03 \pm 0.03 \times 10^{3} \mu \mathrm{L}$ in the naive control rats (Figure 2(a)). The exudates of the vehicletreated control rats presented a significantly increased total leucocyte count of $0.70 \pm 0.11 \times 10^{3} \mu \mathrm{L}$ compared to the naïve control rats (Figure 2(a)). A. micraster extract at 30 , 100 , and $300 \mathrm{mg} / \mathrm{kg}$ significantly $(p<0.01$ ) inhibited the extravasation of leucocyte into the pleural cavity by $57.14 \pm$ $10.10 \%, 60.71 \pm 6.84 \%$, and $64.29 \pm 9.22 \%$, respectively, compared to the vehicle-treated control (Figure 2(a)). Similarly, diclofenac significantly suppressed the total leucocyte count to $0.40 \pm 0.08 \times 10^{3} \mu \mathrm{L}$. With a differential count made, the exudates of the naïve control rats had $0.02 \pm 0.02 \times 10^{3} \mu \mathrm{L}$ neutrophils (Figure 2(b)) which was significantly elevated to $0.47 \pm 0.09 \times 10^{3} \mu \mathrm{L}$ in the vehicle-treated control. The extract at the doses used also significantly $(p<0.05)$ inhibited neutrophil infiltration into the pleural cavity by $47.84 \pm 10.34 \%, 47.94 \pm 12.56 \%$, and $50.53 \pm 7.73 \%$, respectively, whereas diclofenac significantly suppressed the neutrophil count by $44.68 \pm 12.66 \%$ (Figure 2(b)). Lymphocyte numbers in the naïve control rats were below detectable levels (Figure 2(c)). However, on induction of pleurisy there was significant extravasation of these mononuclear cells into the pleural cavity to $0.04 \pm 0.01 \times 10^{3} \mu \mathrm{L}$ in the vehicle-treated control (Figure 2(c)). The extract at the doses administered 


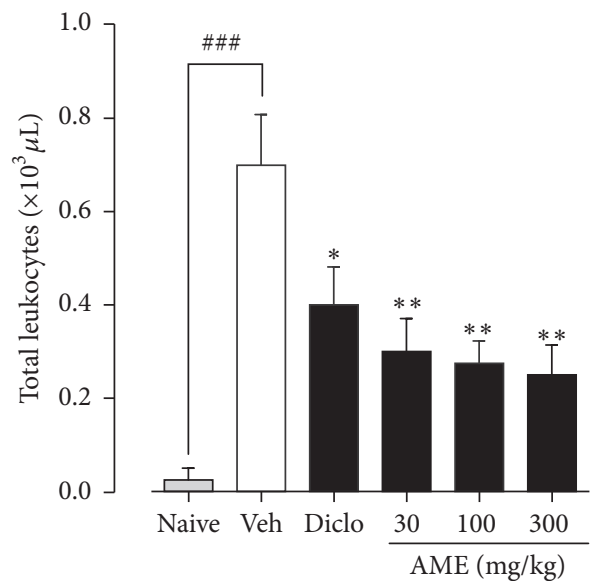

(a)

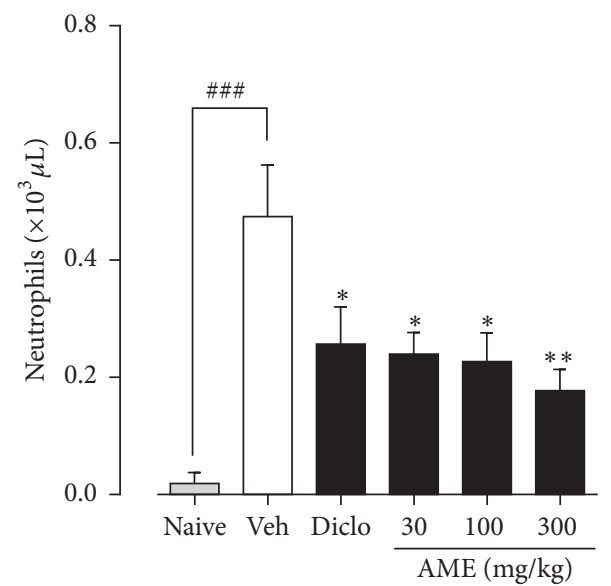

(b)

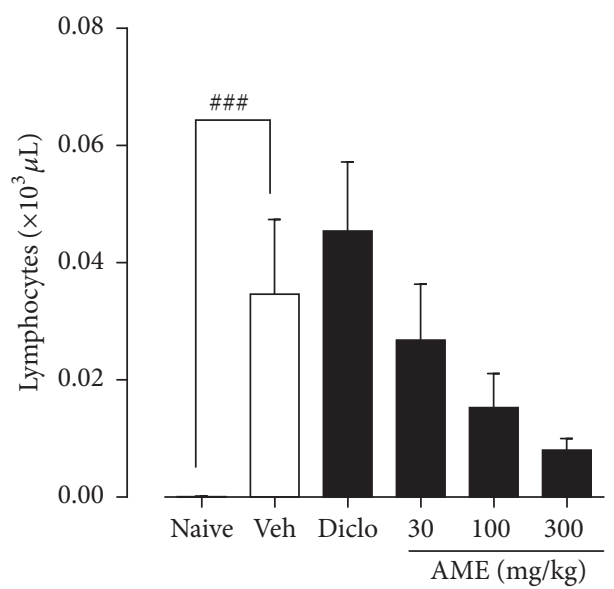

(c)

FIGURE 2: Effect of Antrocaryon micraster on leucocyte count in carrageenan-induced pleurisy in rats. Sprague Dawley rats (200-250 g) were untreated or treated with either normal saline $(5 \mathrm{ml} / \mathrm{kg})$, diclofenac $(10 \mathrm{mg} / \mathrm{kg})$, or AME $(30-300 \mathrm{mg} / \mathrm{kg})$ p.o. Pleurisy was induced as described in the Methods. The total and differential leucocyte count were conducted. Data is presented as mean \pm SEM $(n=5)$. ${ }^{*} p<0.05$ and ${ }^{* *} p<0.01$ compared to the vehicle-treated group; ${ }^{\# \#} p<0.001$ compared to naive control (one-way ANOVA followed by Dunnett's post hoc test).

did not have any statistically significant inhibition on the extravasation of mononuclear cells. Lymphocyte count of $0.05 \pm 0.01 \times 10^{3} \mu \mathrm{L}$ was obtained in the diclofenac-treated group (Figure 2(c)).

4.1.3. Effect of Antrocaryon micraster Extract on Lung Histopathology. Histological examination of the H\&E-stained lung sections of the naive control animals showed normal architecture with no signs of damage, haemorrhage, oedema, or inflammatory cells (Figure 3(a)). In the vehicle-treated control group there was damage to lung tissues characterized by a significant distortion of the lung histological architecture, massive infiltration of inflammatory cells, oedema, and haemorrhage (Figure 3(b)). A. micraster extract when administered at $30-300 \mathrm{mg} / \mathrm{kg}$ significantly reduced the degree of lung injury by offering some protection. The histological architecture of the lungs was mostly preserved and there was a significantly reduced numbers of infiltrating cells and less oedema and haemorrhage when compared with the vehicle-treated control animals (Figures 3(d)-3(f)). Administration of diclofenac protected against lung tissue damage and reduced the oedema, haemorrhage, and the number of infiltrating cells (Figure 3(c)).

\subsection{Biochemical Assays for Oxidative Stress Markers}

4.2.1. Effect of Antrocaryon micraster Extract on Oxidative Stress Markers. Carrageenan-induced oxidative stress in the test animals was evidenced by a statistically significant decrease in the measured levels of GSH and expression of SOD and CAT in the vehicle-treated control animals when compared to the naïve controls (Figures 4(a)-4(c)). The level of GSH in the naïve control group of $85.70 \pm 4.45 \mu \mathrm{mol} / \mathrm{mg}$ protein was significantly reduced in the vehicle-treated control group to $31.45 \pm 2.10 \mu \mathrm{mol} / \mathrm{mg}$ protein (Figure $4(\mathrm{a})$ ). A. micraster extract at 30,100 , and $300 \mathrm{mg} / \mathrm{kg}$ significantly increased levels of GSH to $43.72 \pm 8.15 \mu \mathrm{mol} / \mathrm{mg}$ protein, $60.29 \pm 9.60 \mu \mathrm{mol} / \mathrm{mg}$ protein, and $68.37 \pm 6.66 \mu \mathrm{mol} / \mathrm{mg}$ protein, respectively, in comparison to the vehicle-treated 


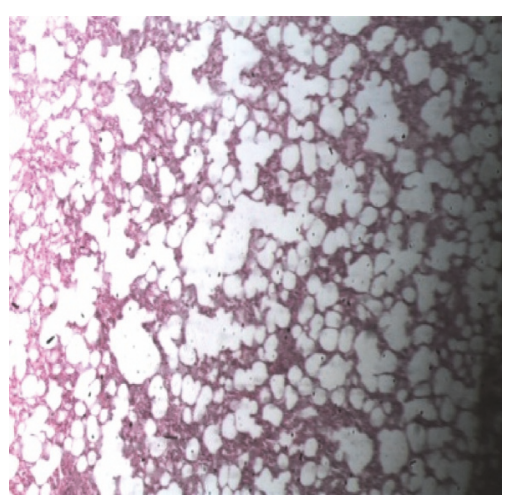

(a)

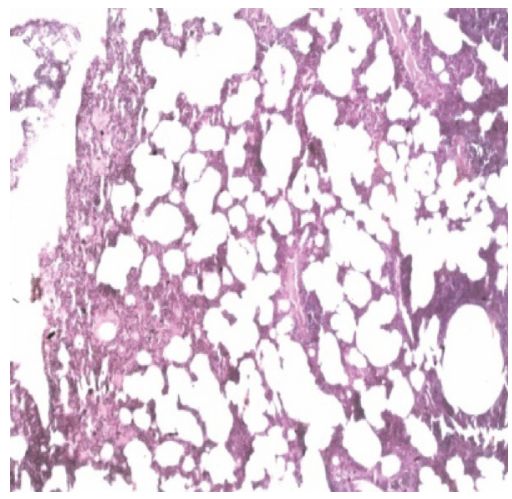

(d)

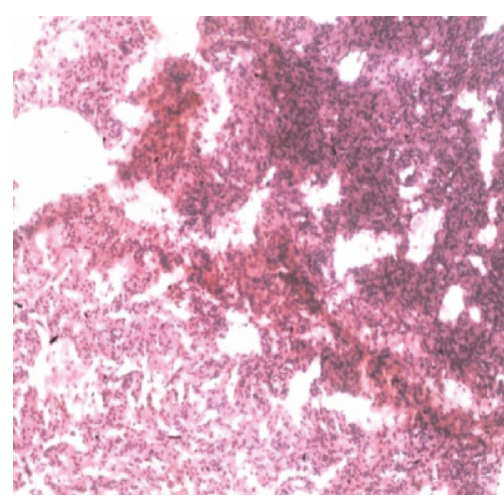

(b)

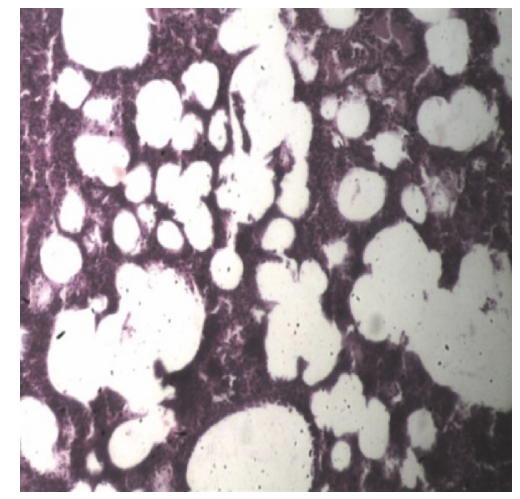

(e)

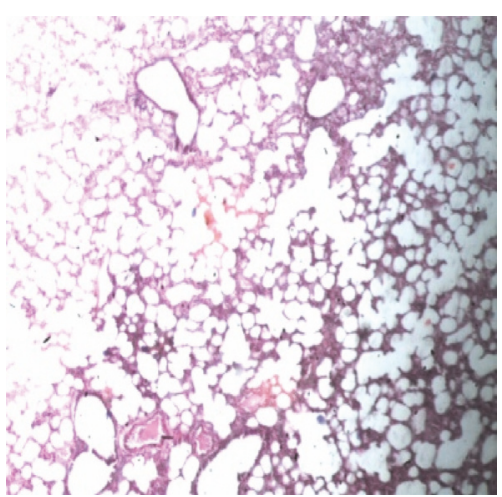

(c)

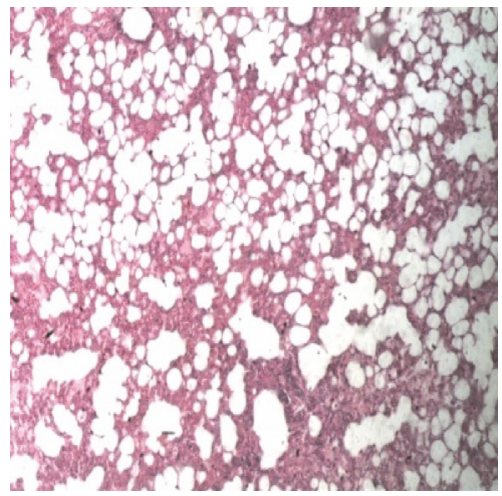

(f)

Figure 3: Effect of Antrocaryon micraster extract on histopathological changes in lung tissues of rats with carrageenan-induced pleurisy. Sprague Dawley rats (200-250 g) were untreated or treated with either normal saline (5 ml/kg), diclofenac (10 mg/kg), or AME $(30-300 \mathrm{mg} / \mathrm{kg})$ p.o. Pleurisy was induced as described in Methods. Lung tissues were fixed in formalin (10\%), processed, and stained with H\&E. Representative photomicrographs of the histology of lung tissues are shown. Naïve control (a), vehicle-treated control (b), diclofenac $10 \mathrm{mg} / \mathrm{kg}$ (c), AME $30 \mathrm{mg} / \mathrm{kg}$ (d), AME $100 \mathrm{mg} / \mathrm{kg}$ (e), and AME $300 \mathrm{mg} / \mathrm{kg}$ (f).

control rats, while in the diclofenac-treated rats a GSH concentration of $30.08 \pm 2.34 \mu \mathrm{mol} / \mathrm{mg}$ protein was obtained (Figure 4(a)).

The expression of SOD in naïve control rats at $0.90 \pm 0.20$ units/mg protein was significantly reduced to $0.07 \pm 0.02$ units/mg protein in the vehicle-treated control group (Figure 4(b)). A. micraster extract at the stated doses significantly increased the expression of SOD to $0.70 \pm 0.13$ units $/ \mathrm{mg}$ protein, $0.80 \pm 0.16$ units/mg protein, and $0.92 \pm 0.14$ units $/ \mathrm{mg}$ protein, respectively, compared to the vehicle-treated control group while in the diclofenac-treated rats SOD concentration was $0.30 \pm 0.07 / \mathrm{mg}$ protein (Figure $4(\mathrm{~b})$ ).

In the naive control group CAT measured $1.92 \pm 0.17$ units/mg protein and was significantly reduced to $1.06 \pm$ 0.17 munits/mg protein in the vehicle-treated control group (Figure 4(c)). However, A. micraster extract at the same doses significantly increased the expression of CAT to $1.12 \pm$ 0.17 munits $/ \mathrm{mg}$ protein, $1.61 \pm 0.1$ munits $/ \mathrm{mg}$ protein, and $1.99 \pm 0.17$ munits/mg protein, respectively, compared to the disease vehicle-treated control. Diclofenac-treated rats presented with CAT expression of $1.05 \pm 0.07$ munits $/ \mathrm{mg}$ protein (Figure $4(\mathrm{c})$ ).
Increased expression of MPO and MDA levels was observed as marker for the induction of oxidative stress by carrageenan in the disease vehicle-treated control animals (Figures $4(\mathrm{~d})$ and $4(\mathrm{e})$ ) relative to the naïve rats. The disease vehicle-treated control group had a statistically significant increased MPO activity of $101.2 \pm 22.58$ units/mg protein relative to naïve control group of $11.01 \pm 2.67 \mathrm{units} / \mathrm{mg}$ protein (Figure 4(d)). A. micraster extract significantly reduced the expression of MPO to $51.22 \pm 13.00$ units/mg protein, $27.42 \pm$ 3.46 units/mg protein, and $28.83 \pm 3.23$ units $/ \mathrm{mg}$ protein, respectively, relative to the vehicle-treated control group. A level of $89.06 \pm 9.40 / \mathrm{mg}$ protein was obtained in the diclofenac-treated group (Figure 4(d)).

MDA level in naïve control group was $54.77 \pm$ $6.76 \mathrm{nmol} / \mathrm{mg}$ protein with the vehicle-treated control group significantly increasing it to $121.0 \pm 9.59 \mathrm{nmol} / \mathrm{mg}$ protein (Figure 4(e)). Similar statistically significant reductions in MDA to $76.28 \pm 9.17 \mathrm{nmol} / \mathrm{mg}$ protein, $63.01 \pm 7.87 \mathrm{nmol} / \mathrm{mg}$ protein, and $63.07 \pm 12.05 \mathrm{nmol} / \mathrm{mg}$ protein, respectively, compared to the vehicle control group were obtained at the three respective doses of the extract. Relative to the disease vehicle-treated control group, diclofenac decreased 


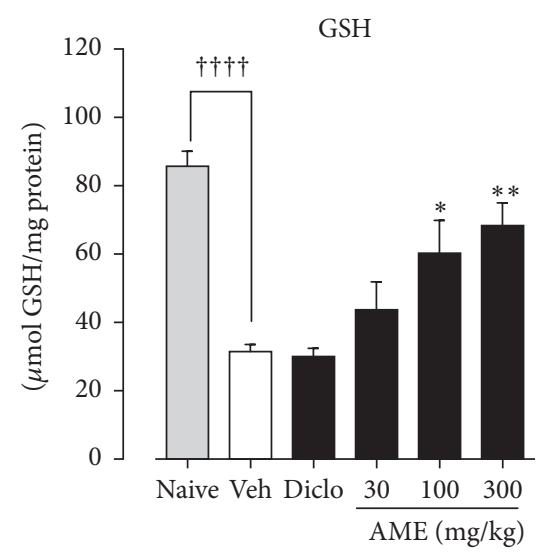

(a)

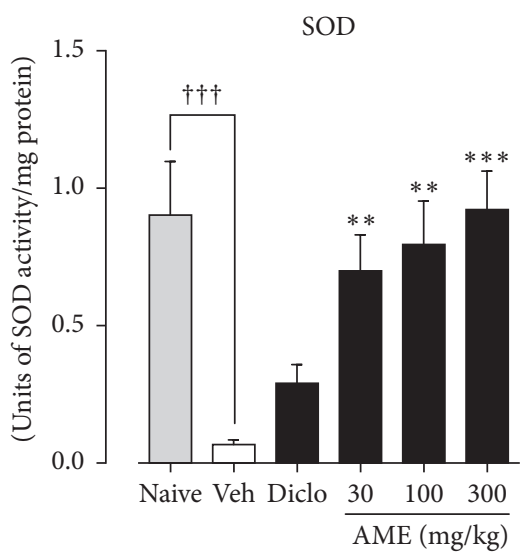

(b)

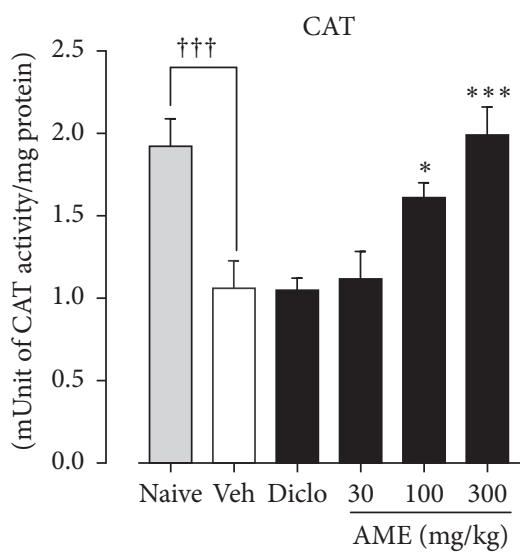

(c)

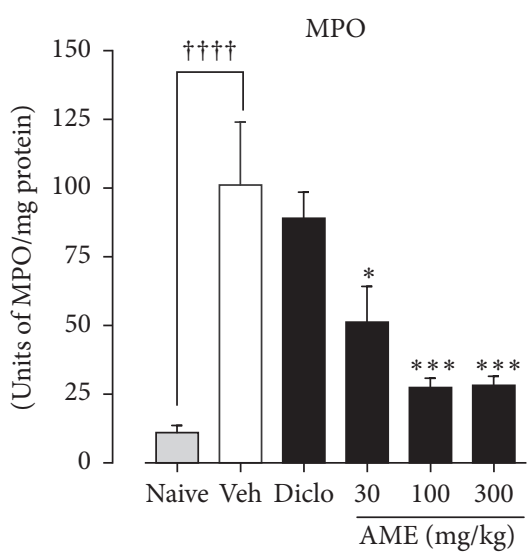

(d)

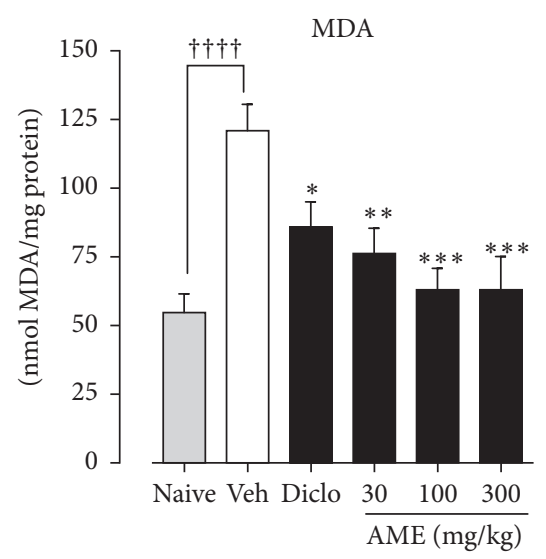

(e)

Figure 4: Anti-oxidant effect of Antrocaryon micraster extract on carrageenan-induced pleurisy in rats. Sprague Dawley rats (200-250 g) were untreated or treated with either normal saline $(5 \mathrm{ml} / \mathrm{kg})$, diclofenac $(10 \mathrm{mg} / \mathrm{kg})$, or AME $(30-300 \mathrm{mg} / \mathrm{kg})$ p.o. for 3 days. Pleurisy was induced as described in the Methods. Lung homogenates were assayed for GSH (a), SOD (b), CAT (c), MPO (d), and MDA (e). Data is presented as mean \pm SEM $(n=5) .{ }^{*} p<0.05,{ }^{* *} p<0.01$, and ${ }^{* * *} p<0.001$ compared to vehicle-treated control; ${ }^{\dagger \dagger \dagger} p<0.001$ and ${ }^{\dagger+\dagger} p<0.0001$ compared to naïve control (one-way ANOVA followed by Dunnett's post hoc test).

the concentration of MDA to $85.93 \pm 9.17 \mathrm{nmol} / \mathrm{mg}$ protein (Figure 4(e)).

\subsection{The Effect of Antrocaryon micraster Extract on Carra-} geenan-Induced Paw Oedema. Injection of the carrageenan suspension into the right hind paws of the test mice produced a time-dependent increase in paw thickness which peaked at the $2 \mathrm{~h}$ and was significantly and dose-dependently reduced by the prophylactic administration of $A$. micraster extract. The maximal oedema response was suppressed by $20.34 \pm$ $1.70 \%, 40.48 \pm 2.22 \%$, and $66.43 \pm 3.54 \%$, respectively, at 30,100 , and $300 \mathrm{mg} / \mathrm{kg}$ of AME compared with the vehicletreated control (Figure 5(a)). Total oedema over the $6 \mathrm{~h}$ was also suppressed by $30.86 \pm 7.38 \%, 45.55 \pm 4.40 \%$, and $66.68 \pm 8.60 \%$, respectively, compared with the vehicle-treated control (Figure 5(b)). At the same doses in the curative protocol, $A$. micraster extract significantly $(p<0.05)$ reduced maximal oedema response by $26.77 \pm 2.78 \%, 33.13 \pm 1.95 \%$, and $50.11 \pm 4.99 \%$, respectively (Figure 5(c)), and inhibited total oedema response by $39.11 \pm 5.69 \%, 40.37 \pm 4.15 \%$, and $55.45 \pm 4.25 \%$, respectively, compared to the vehicle-treated control (Figure 5(d)). As was expected, diclofenac inhibited both the maximal and total oedema responses by $50.85 \pm$ $2.87 \%$ and $50.52 \pm 3.82 \%$, respectively, in the preventive protocol and $50.73 \pm 4.22 \%$ and $50.13 \pm 2.48 \%$, respectively, in the curative protocol (Figures 5(a)-5(d)).

4.4. Phytochemical Screening. Phytochemical analysis of the ethanolic stem bark of $A$. micraster tested positive for the presence of saponins, alkaloids, triterpenoids, and both hydrolysable and condensed tannins.

4.5. Acute Toxicity. There was no death recorded within $24 \mathrm{~h}$ and up to 14 days of observation. The doses of $A$. micraster again did not cause any apparent changes associated with autonomic or central nervous system or neurotoxicity. The $\mathrm{LD}_{50}$ for the $A$. micraster extract is greater than $3000 \mathrm{mg} / \mathrm{kg}$.

\section{Discussion}

In this study, the effect of Antrocaryon micraster extract on acute inflammation was evaluated in two related experiments 


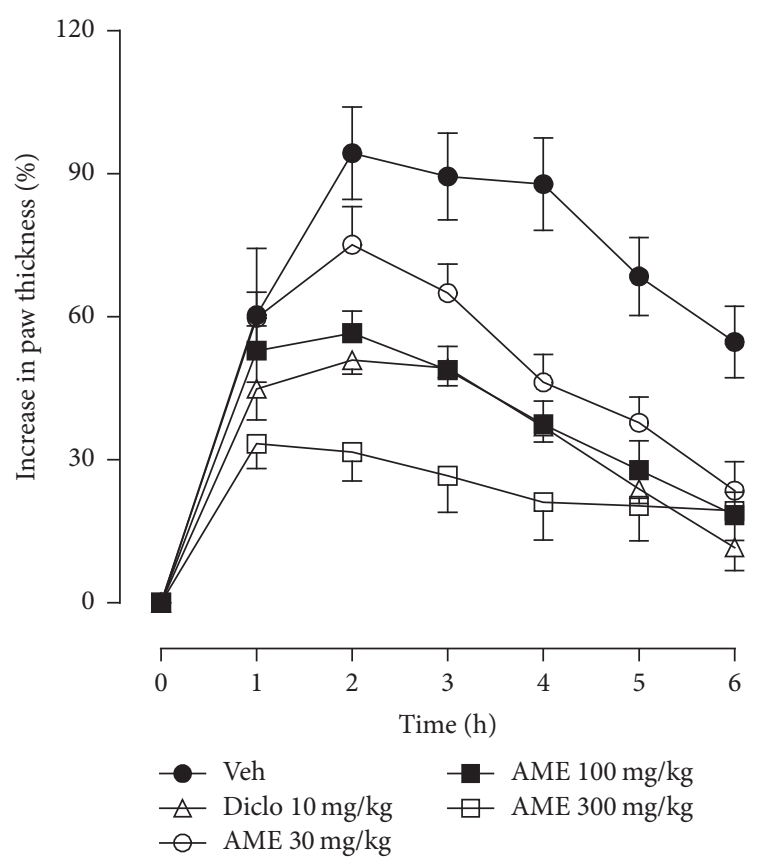

(a)

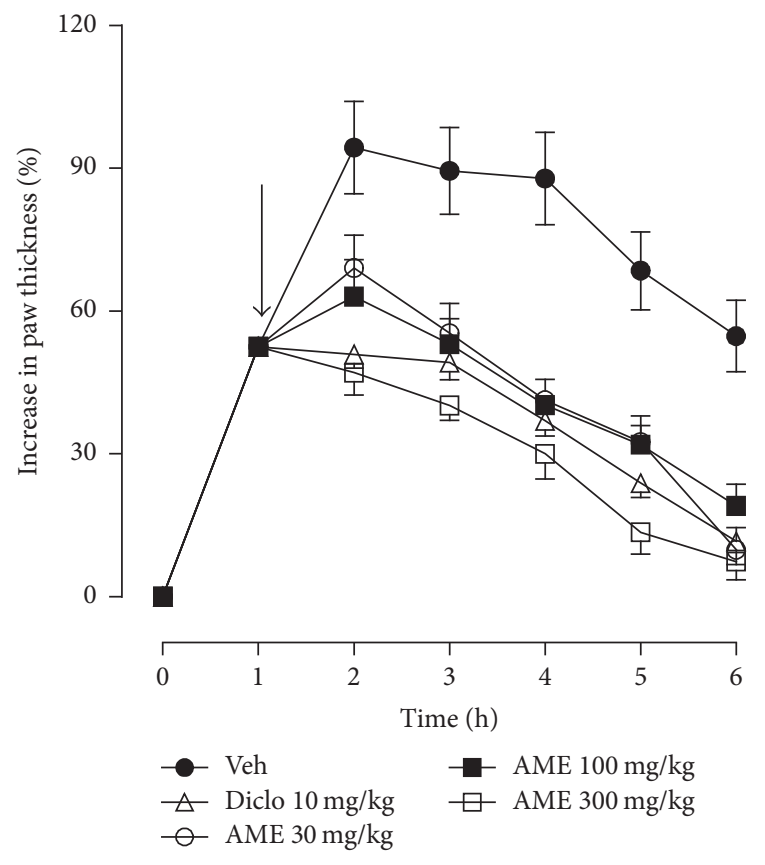

(c)

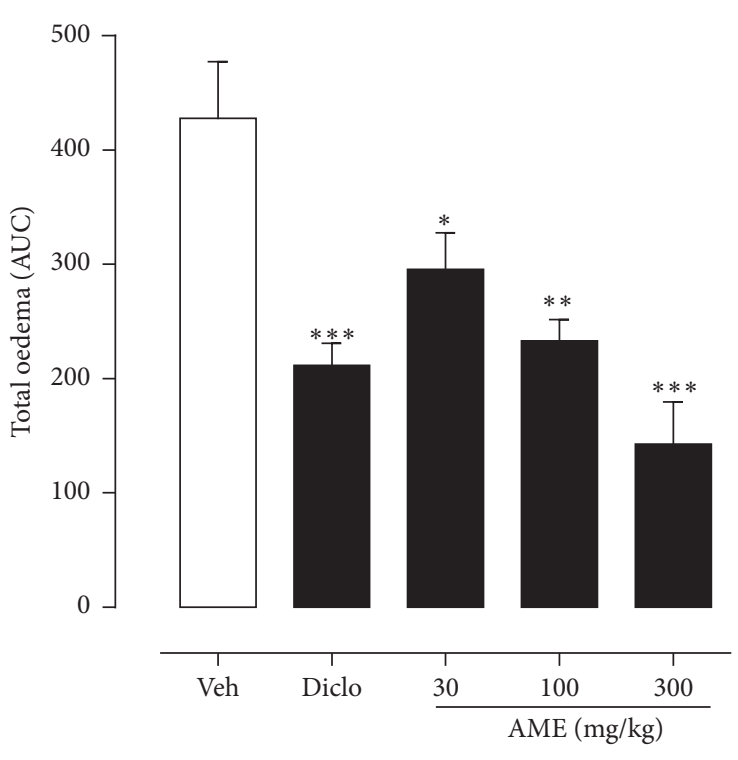

(b)

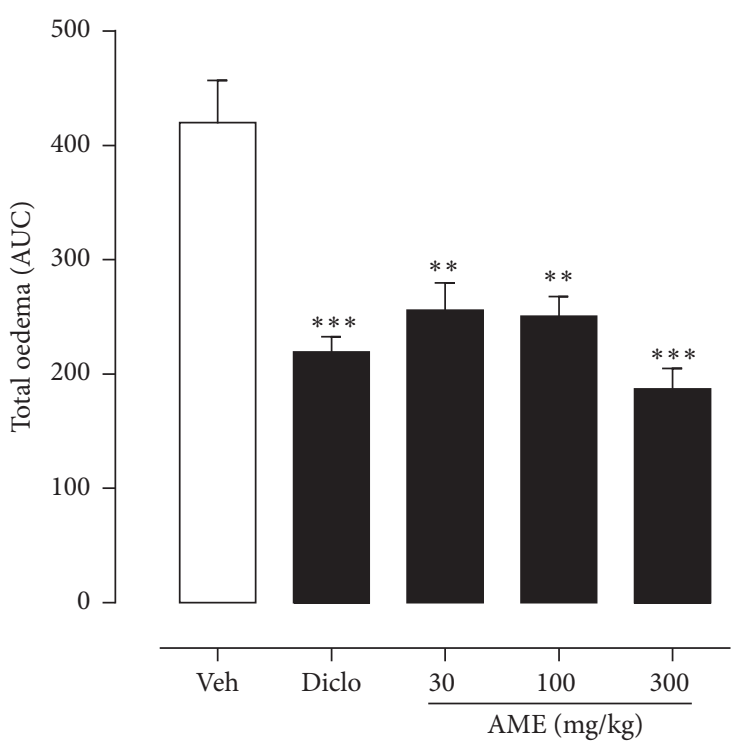

(d)

Figure 5: Effect of Antrocaryon micraster extract on carrageenan-induced paw oedema in mice. Oedema was induced and monitored as described in the Methods. Percentage increase in paw thickness (a and c) and total oedema induced during the $6 \mathrm{~h}$ was calculated as area under the time course curves, AUC (b and d). Drug vehicle, AME 30-300 mg/kg, and diclofenac $100 \mathrm{mg} / \mathrm{kg}$ were given in the prophylactic (top panel) or curative protocol (bottom panel). Data is presented as mean $\pm \operatorname{SEM}(n=5) .{ }^{*} p<0.05,{ }^{* *} p<0.01$, and ${ }^{* * *} p<0.001$ compared to vehicle-treated group (one-way ANOVA followed by Dunnett's post hoc test). Arrow indicates point of extract administration in the curative protocol.

in which carrageenan was used to induce pleurisy and pedal oedema, respectively, in rats and mice. We could show that, in the pleurisy model, the extract exhibited significant inhibitory effects on cellular infiltration, as well as fluid and protein leakage into the pleural cavity. Again, pretreatment with the extract protected against lung tissue damage through a significant reduction in cellular infiltration, oedema, and haemorrhage to the lung tissues. Tissue 
levels of the oxidative stress markers GSH and expression of SOD and CAT were increased while levels of MDA and MPO were reduced. In the pedal oedema model, the maximal and total oedema responses, respectively, in mice were significantly suppressed even when the extract was given prophylactically or curatively. Our results demonstrate that the effect of the extract on the paw oedema study is in consonance with that obtained in the pleurisy study and further validates the suppressive effect of $A$. micraster extract on acute inflammation.

The carrageenan-induced paw oedema model is wellcharacterized, standardized [26, 27], and employed largely in the study of mechanisms involved in the inflammatory response and predominantly leucocyte-driven reactions and for screening potential anti-inflammatory agents that have effects on such reactions $[28,29]$. The development of oedema after the carrageenan injection happens in two phases. In the early phase, autocoids such as serotonin and histamine are implicated and this phase lasts for about an hour. Prostaglandins and the induction of cyclooxygenase-2 (COX2) predominate in the late phase which stretches from 1 to $6 \mathrm{~h}[30,31]$. Prostaglandins act together with vasoactive substances to increase vascular permeability and enhance the accumulation of fluids in the tissues [32]. Again, in response to the injected phlogistic agent, leucocytes become activated. There is incomplete reduction of oxygen within the cell leading to the production of reactive oxygen species (ROS) also called free radicals notably superoxide anion $\left(\mathrm{O}_{2}{ }^{-}\right)$and hydroxyl radical $\left(\mathrm{HO}^{-}\right)$[33] and the peroxidation of lipid membranes. When large amounts of ROS are generated by leucocytes during respiratory burst it leads to oxidative stress and tissue injury and remodelling [34, 35] through the modulation of the release of mediators and regulate the expression of adhesion molecules [36, 37]. A battery of antioxidant molecules such as GSH, SOD, and CAT act on the free radicals when generated. However, oxidative stress occurs when these defence mechanisms are overwhelmed or depleted. Oxidative stress has been implicated in the aetiology of many inflammatory disease models including pleurisy induced by carrageenan administration. An extract that increases these antioxidants tends to protect against damage to tissues. Our results show A. micraster extract inhibited the effect of oxidative stress by increasing the levels of GSH and expression of SOD and CAT while reducing MPO activity and MDA level. Increased GSH and SOD and CAT have been established as a result of the inhibition of their depletion and/or an augmentation in their production, in response to the induced oxidative stress [38, 39]. The tissue levels of MDA and activity of MPO correlate with the number of infiltrating cells in the tissue [40]. Analysis of the pleural fluid obtained from the extract-treated test animals showed reduced numbers of leucocytes, which explains the reduced MPO activity and MDA levels. The administration of $A$. micraster extract possibly affected these parameters by inhibiting the infiltration and effect of activated leucocytes in the tissues. This was confirmed by the histopathological findings which showed reduced number of cellular infiltration as well as attenuated lung tissue damage with the extract administration. In a previous study carried out in the absence of pathology and in which daily administration was done for 28 days, diclofenac is documented to increase the activity of SOD but not CAT [41]. However, in our study, diclofenac did not have significant effects on the activity of MPO, expression of SOD and CAT, and the levels of GSH but decreased the levels of MDA. In the present study, diclofenac was administered daily at $10 \mathrm{mg} / \mathrm{kg}$ for 3 days and its effect on carrageenan-induced oxidative stress evaluated. Diclofenac reduced exudate volume and protein leakage into pleural cavity. This way, it prevented oxidative stress, but not through increasing the levels of antioxidants. Our results are consistent with previous findings that doses above $80 \mathrm{mg} / \mathrm{kg}$ of diclofenac have been used to induce oxidative stress [42, 43] even though lower doses inhibit oxidative stress. The extract demonstrated dose-dependent inhibitory effects on acute inflammation when administered both prophylactically and curatively in the paw oedema test. This is interesting because it has been shown previously that proven antiinflammatory activity for a drug which is administered before initiation of the inflammatory response does not necessarily imply an ability to act curatively. For example, it was shown in rats that preemptive administration of cyclosporin prevented the onset of collagen-induced inflammation but treatment with the drug after the onset of disease rather exacerbated the condition [44].

In this study, the phytochemicals identified in the crude extract of $A$. micraster were tannins, saponins, triterpenoids, and alkaloids. It is not surprising therefore that $A$. micraster extract exhibited anti-inflammatory activity. In support of this finding it has been previously reported these phytochemicals possess anti-inflammatory activity in various disease models of inflammation. For example, the tannins present in Punica granatum exhibited anti-inflammatory activity through the inhibition of nitric oxide synthase [45], saponins derived from Platycodon grandiflorum inhibited carrageenan-induced inflammation in rats [46], and the triterpenoid pristimerin derived from the Celastraceae family modulates cellular and soluble immune mediators of inflammation [47]. Previously, we had also shown that the total alkaloid extract of Picralima nitida seeds has antiinflammatory activity [48]. The dose-dependent suppression of carrageenan-induced mouse pedal oedema by the extract could most likely indicate that one or more of the constituent compounds potentially inhibited the acute phase of inflammatory processes though the precise mechanism of action of A. micraster extract is yet to be determined. The constituent bioactive compounds in plant extracts impact on the toxicity of the plant $[49,50]$. There was no death and no apparent behavioural changes observed within $24 \mathrm{~h}$ and up to 14 days of observation. Thus A. micraster extract has no immediate or delayed physically apparent acute toxicity effect and has an LD50 greater than $3000 \mathrm{mg} / \mathrm{kg}$.

Taken together, the ethanolic stem-bark extract of $A$. micraster has antioxidant effects and significantly inhibits carrageenan-induced inflammation in murine models.

\section{Conflicts of Interest}

The authors declare that they have no conflicts of interest. 


\section{Acknowledgments}

The authors are grateful to Messrs Clifford A. Osafo and Gordon Darku, Technicians of the Departments of Herbal Medicine and Pharmacology, respectively, Faculty of Pharmacy and Pharmaceutical Sciences, College of Health Sciences, Kwame Nkrumah University of Science and Technology (KNUST), Kumasi, Ghana, for technical assistance.

\section{References}

[1] IUCN (International Union for the Conservation of Nature), "IUCN Red List of threatened species. IUCN Global Species Programme Red List Unit, 2011".

[2] W. Hawthorne and C. Jongkind, Woody plants of western African forests: a guide to the forest trees, shrubs and lianes from Senegal to Ghana, Royal Botanic Gardens, Kew, Uk, 2006.

[3] P. Addo-Fordjour, E. J. D. Belford, and D. Akonnor, "Diversity and conservation of medicinal plants in the Bomaa community of the Brong Ahafo region," Ghana. Journal of Medicinal Plants Research, vol. 2, no. 9, pp. 226-233, 2013.

[4] M. Bahmani, A. Zargaran, M. Rafieian-Kopaei, and K. Saki, "Ethnobotanical study of medicinal plants used in the management of diabetes mellitus in the Urmia, Northwest Iran," Asian Pacific Journal of Tropical Medicine, vol. 7, no. 1, pp. S348-S354, 2014.

[5] B. Y. Vigbedor, A. S. Osafo, and B. A. Gyan, "Ethnobotanical survey of plants used in the treatment of malaria in the sekyere central district of ashanti region of Ghana," International Journal of Novel Research in Life Sciences, vol. 2, no. 6, pp. 17-25.

[6] J. Ayarkwa, "Antrocaryon micraster," in Plant Resources of Tropical Africa Databank for Commodity Group 2. Timbers 2. PROTA Foundation, D. Louppe, A. A. Oteng-Amoako, and M. Brink, Eds., Backhuys Publishers, Wageningen, Netherlands, 2012.

[7] K. J. O’Byrne, A. G. Dalgleish, M. J. Browning, W. P. Steward, and A. L. Harris, "The relationship between angiogenesis and the immune response in carcinogenesis and the progression of malignant disease," European Journal of Cancer, vol. 36, no. 2, pp. 151-169, 2000.

[8] M. Arita, "Mediator lipidomics in acute inflammation and resolution," Journal of Biochemistry, vol. 152, no. 4, pp. 313-319, 2012.

[9] B. D. Levy and C. N. Serhan, "Resolution of acute inflammation in the lung," Annual Review of Physiology, vol. 76, pp. 467-492, 2014.

[10] A. Mantovani, S. K. Biswas, M. R. Galdiero, A. Sica, and M. Locati, "Macrophage plasticity and polarization in tissue repair and remodelling," The Journal of Pathology, vol. 229, no. 2, pp. 176-185, 2013.

[11] E. Ricciotti and G. A. Fitzgerald, "Prostaglandins and inflammation," Arteriosclerosis, Thrombosis, and Vascular Biology, vol. 31, no. 5, pp. 986-1000, 2011.

[12] I. Helenius, A. Lumme, and T. Haahtela, "Asthma, airway inflammation and treatment in elite athletes," Sports Medicine, vol. 35, no. 7, pp. 565-574, 2005.

[13] J. Burisch, T. Jess, M. Martinato, and P. L. Lakatos, "The burden of inflammatory bowel disease in Europe," Journal of Crohn's and Colitis, vol. 7, no. 4, pp. 322-337, 2013.

[14] I. Tabas and C. K. Glass, "Anti-inflammatory therapy in chronic disease: challenges and opportunities," Science, vol. 339, no. 6116, pp. 166-172, 2013.
[15] M. Rafieian-Kopaei, "Medicinal plants and the human needs," Journal of HerbMed Pharmacology, vol. 1, no. 1, pp. 1-2, 2011.

[16] T. S. F. Saleh, J. B. Calixto, and Y. S. Medeiros, "Anti-inflammatory effects of theophylline, cromolyn and salbutamol in a murine model of pleurisy," British Journal of Pharmacology, vol. 118, no. 3, pp. 811-819, 1996.

[17] G. L. Ellman, “Tissue sulfhydryl groups," Archives of Biochemistry and Biophysics, vol. 82, no. 1, pp. 70-77, 1959.

[18] H. P. Misra and I. Fridovich, "The role of superoxide anion in the autoxidation of epinephrine and a simple assay for superoxide dismutase," The Journal of Biological Chemistry, vol. 247, no. 10, pp. 3170-3175, 1972.

[19] A. K. Sinha, "Colorimetric assay of catalase," Analytical Biochemistry, vol. 47, no. 2, pp. 389-394, 1972.

[20] M. Şenoğlu, E. B. Kurutas, I. Altun et al., "Myeloperoxidase activities in polymorphonuclear leucocytes in lumbar disc disease," Journal of Neurological Sciences, vol. 26, no. 3, 2009.

[21] R. L. Heath and L. Packer, "Photoperoxidation in isolated chloroplasts. I. Kinetics and stoichiometry of fatty acid peroxidation," Archives of Biochemistry and Biophysics, vol. 125, no. 1, pp. 189-198, 1968.

[22] C. A. Winter, E. A. Risley, and G. W. Nuss, "Carrageenininduced edema in hind paw of the rat as an assay for antiiflammatory drugs," Proceedings of the Society for Experimental Biology and Medicine, vol. 3, pp. 544-547, 1962.

[23] A. Sofowora, Medicinal Plants and Traditional medicine in Africa, Spectrum Books Limited, Ibadan, Nigeria, 2nd edition, 1993.

[24] W. C. Evans, "Phytochemical variation within a species," in Trease and Evans Pharmacognosy, pp. 80-90, W.B. Saunders Company, Edinburgh, Scotland, 15th edition, 2002.

[25] S. Irwin, "Comprehensive observational assessment: Ia. A systematic, quantitative procedure for assessing the behavioral and physiologic state of the mouse," Psychopharmacologia, vol. 13, no. 3, pp. 222-257, 1968.

[26] N. K. Jain, C. S. Patil, A. Singh, and S. K. Kulkarni, "A simple technique to evaluate inflammatory pain along with anti-inflammatory studies in carrageenan-induced paw edema," Indian Journal of Pharmacology, vol. 33, no. 2, p. 114, 2001.

[27] M. S. Paschapur, M. B. Patil, R. Kumar, and S. R. Patil, "Evaluation of anti-inflammatory activity of ethanolic extract of Borassus flabellifer L. male flowers (inflorescences) in experimental animals," Journal of Medicinal Plants Research, vol. 3, no. 2, pp. 049-054, 2009.

[28] M. Petersson, U. Wiberg, T. Lundeberg, and K. Uvnäs-Moberg, "Oxytocin decreases carrageenan induced inflammation in rats," Peptides, vol. 22, no. 9, pp. 1479-1484, 2001.

[29] J. M. Sini, A. H. Yaro, L. O. Ayanwuyi, O. M. Aiyelero, S. M. Mallum, and K. S. Gamaniel, "Antinociceptive and anti-inflammatory activities of the aqueous extract of the root bark of Combretum sericeum in rodents," African Journal of Biotechnology, vol. 9, no. 51, p. 8872, 2010.

[30] J. Necas and L. Bartosikova, "Carrageenan: a review," Veterinarni Medicina, vol. 58, no. 4, pp. 187-205, 2013.

[31] H. Sadeghi, V. Hajhashemi, M. Minaiyan, A. Movahedian, and A. Talebi, "A study on the mechanisms involving the antiinflammatory effect of amitriptyline in carrageenan-induced paw edema in rats," European Journal of Pharmacology, vol. 667, no. 1-3, pp. 396-401, 2011.

[32] A. R. Crecelius, B. S. Kirby, J. C. Richards et al., "Mechanisms of ATP-mediated vasodilation in humans: Modest role for nitric 
oxide and vasodilating prostaglandins," American Journal of Physiology - Heart and Circulatory Physiology, vol. 301, no. 4, pp. H1302-H1310, 2011.

[33] K. Apel and H. Hirt, "Reactive oxygen species: metabolism, oxidative stress, and signal transduction," Annual Review of Plant Biology, vol. 55, pp. 373-399, 2004.

[34] A. Fernández-Sánchez, E. Madrigal-Santillán, M. Bautista et al., "Inflammation, oxidative stress, and obesity," International Journal of Molecular Sciences, vol. 12, no. 5, pp. 3117-3132, 2011.

[35] I. Posadas, M. Bucci, F. Roviezzo et al., "Carrageenan-induced mouse paw oedema is biphasic, age-weight dependent and displays differential nitric oxide cyclooxygenase-2 expression," British Journal of Pharmacology, vol. 142, no. 2, pp. 331-338, 2004.

[36] H. Lum and K. A. Roebuck, "Oxidant stress and endothelial cell dysfunction," The American Journal of Physiology, vol. 280, no. 4, pp. C719-C741, 2001.

[37] Y. S. Bae, H. Oh, S. G. Rhee, and Y. D. Yoo, "Regulation of reactive oxygen species generation in cell signaling," Molecules and Cells, vol. 32, no. 6, pp. 491-509, 2011.

[38] A. Cetinkaya, E. Bulbuloglu, E. B. Kurutas, H. Ciralik, B. Kantarceken, and M. A. Buyukbese, "Beneficial effects of Nacetylcysteine on acetic acid-induced colitis in rats," The Tohoku Journal of Experimental Medicine, vol. 206, no. 2, pp. 131-139, 2005.

[39] E. Birben, U. M. Sahiner, C. Sackesen, S. Erzurum, and O. Kalayci, "Oxidative stress and antioxidant defense," World Allergy Organization Journal, vol. 5, no. 1, pp. 9-19, 2012.

[40] L. Kruidenier and H. W. Verspaget, "Review article: oxidative stress as a pathogenic factor in inflammatory bowel disease-radicals or ridiculous?" Alimentary Pharmacology and Therapeutics, vol. 16, no. 12, pp. 1997-2015, 2002.

[41] E. C. Curcelli, S. S. Muller, and J. L. V. B. Novelli Filho, "Beneficial effects of diclofenac therapy on serum lipids, oxidized low-density lipoprotein and antioxidant defenses in rats," Life Sciences, vol. 82, no. 15-16, pp. 892-898, 2008.

[42] R. S. Devi, S. Narayan, G. Vani, and C. S. Shyamala Devi, "Gastroprotective effect of Terminalia arjuna bark on diclofenac sodium induced gastric ulcer," Chemico-Biological Interactions, vol. 167, no. 1, pp. 71-83, 2007.

[43] B. Berenguer, L. M. Sánchez, A. Quílez et al., "Protective and antioxidant effects of Rhizophora mangle L. against NSAIDinduced gastric ulcers," Journal of Ethnopharmacology, vol. 103, no. 2, pp. 194-200, 2006.

[44] N. Kaibara, T. Hotokebuchi, K. Takagishi, and I. Katsuki, "Paradoxical effects of cyclosporin A on collagen arthritis in rats," Journal of Experimental Medicine, vol. 158, no. 6, pp. 20073015, 1983.

[45] C.-J. Lee, L.-G. Chen, W.-L. Liang, and C.-C. Wang, "Antiinflammatory effects of Punica granatum Linne invitro and in vivo," Food Chemistry, vol. 118, no. 2, pp. 315-322, 2010.

[46] J. Y. Kim, Y. P. Hwang, D. H. Kim et al., "Inhibitory effect of the saponins derived from roots of Platycodon grandiflorum on carrageenan-induced inflammation," Bioscience, Biotechnology and Biochemistry, vol. 70, no. 4, pp. 858-864, 2006.

[47] L. Tong, S. M. Nanjundaiah, S. H. Venkatesha, B. Astry, H. Yu, and K. D. Moudgil, "Pristimerin, a naturally occurring triterpenoid, protects against autoimmune arthritis by modulating the cellular and soluble immune mediators of inflammation and tissue damage," Clinical Immunology, vol. 155, no. 2, pp. 220230, 2014.
[48] E. Woode, D. D. Obiri, C. Ansah, M. Duwiejua, and G. A. Kuffuor, "Total alkaloidal extract of Picralima nitida(fam. Apocynaceae) seeds has anti-inflammatory actions," Journal of Ghana Science Association, vol. 8, no. 1, pp. 70-78, 2006.

[49] S. Bent and R. Ko, "Commonly used herbal medicines in the United States: a review," The American Journal of Medicine, vol. 116, no. 7, pp. 478-485, 2004.

[50] A. Gurib-Fakim, "Medicinal plants: traditions of yesterday and drugs of tomorrow," Molecular Aspects of Medicine, vol. 27, no. 1, pp. 1-93, 2006. 

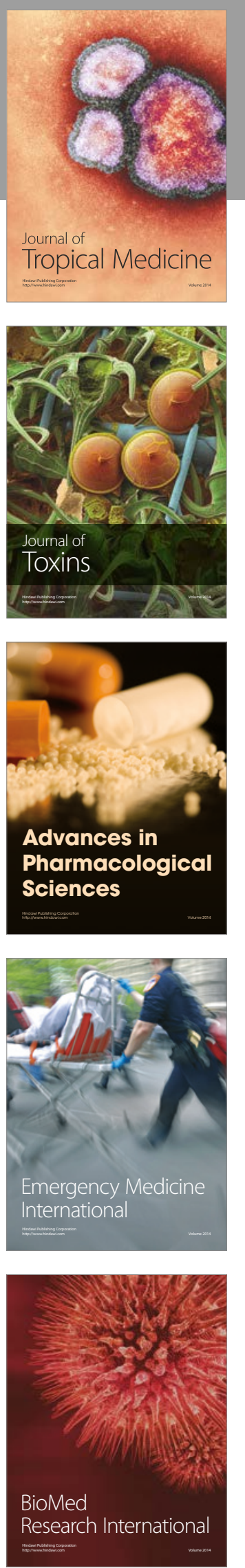
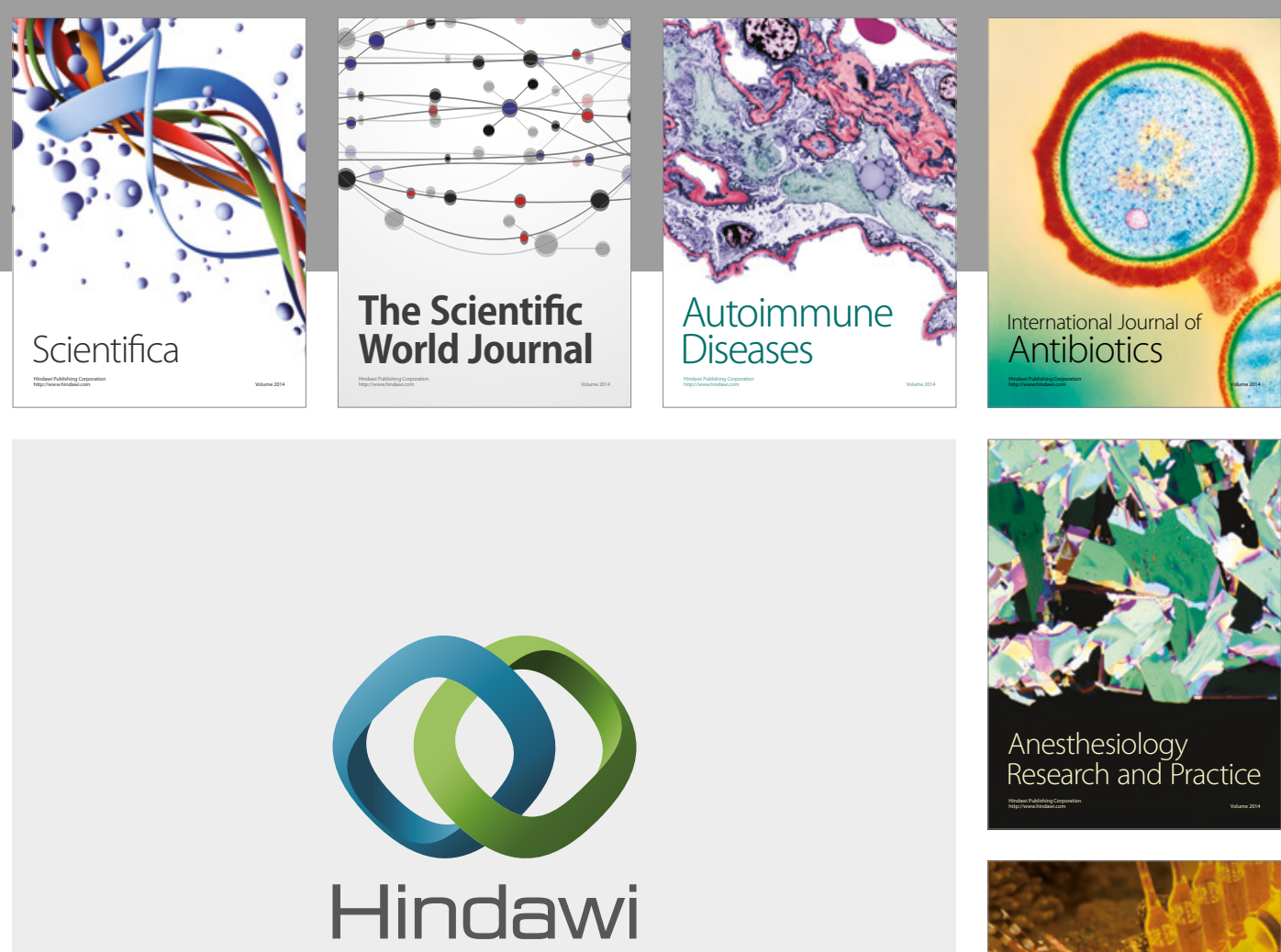

Submit your manuscripts at

https://www.hindawi.com
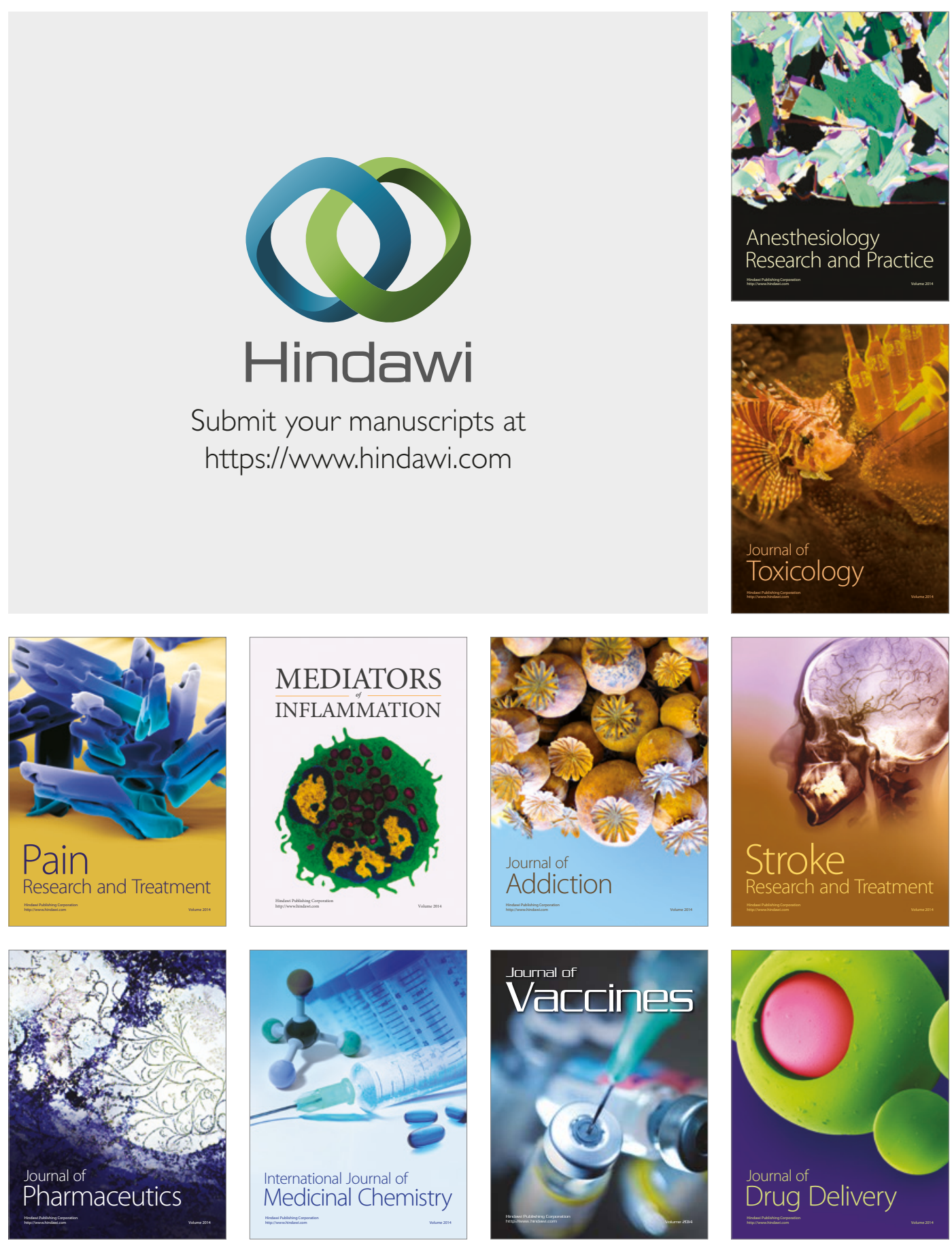